\title{
Airborne Levels of Uranium in the Surroundings of Various Industrial Facilities: Human Health Risks
}

\author{
JOAQUIM ROVIRA \\ Departament d'Enginyeria Quimica, Universitat Rovira i Virgili, Av. Països Catalans 26 \\ 43007 Tarragona, Catalonia, Spain \\ VICTORIA LINARES \\ Physiology Unit, IISPV, Universitat Rovira i Virgili, Sant Llorenç 21 \\ 43201 Reus, Catalonia, Spain \\ MONTSERRAT BELLÉS \\ Physiology Unit, IISPV, Universitat Rovira i Virgili, Sant Llorenç 21 \\ 43201 Reus, Catalonia, Spain \\ MARTÍ NADAL \\ Laboratory of Toxicology and Environmental Health, IISPV, Universitat Rovira i Virgili, Sant Llorenç 21 \\ 43201 Reus, Catalonia, Spain \\ JOSÉ L. DOMINGO \\ Laboratory of Toxicology and Environmental Health, IISPV, Universitat Rovira i Virgili, Sant Llorenç 21 \\ 43201 Reus, Catalonia, Spain \\ E-mail: joseluis.domingo@urv.cat
}

\begin{abstract}
This study was aimed at determining the levels of natural uranium (U) in air samples collected in the surroundings of various industrial facilities: three cement plants, two municipal solid waste incinerators, and a hazardous waste landfill in Catalonia (NE Spain). Although U concentrations were found to be similar or slightly higher than those reported in the scientific literature, the current airborne $U$ levels should not mean any health risks for the population living close to these facilities.
\end{abstract}

Keywords: Uranium; ambient air; industrial facilities; human health risks; Catalonia (Spain).

\section{Introduction}

Uranium (U) is a naturally occurring heavy metal. As this element is present in the environment, it may reach humans through inhalation or dietary exposure, including drinking water. ${ }^{1}$ Chemical $U$ toxicity primarily affects the kidney, causing damage to the proximal tubule, while this metal has been also identified as a potential reproductive toxicant. ${ }^{2,3}$ Most $U$ reaching the body is removed by the kidneys and excreted in the urine in a few days. However, small amounts of this element may accumulate in some tissues of mammals, especially in bone., 5 It means that for certain populations, the chemical toxic effects can be a matter of notable concern, even more important than the radiological effects. In the early days of the Manhattan Project, a very extensive toxicology program on $U$ was carried out. ${ }^{6}$ One of the principal objectives was the establishment of exposure limits for airborne uranium in the workplace based upon uranium's known chemical renal damage.

The population of Catalonia (NE Spain) is more than 7 million people, who are mostly living in the metropolitan area of the capital, Barcelona. In addition to the accumulation of population, Barcelona shows a high density of roads and highways, which intensify the impact of traffic on the environment and the human health. It has been largely demonstrated that traffic 


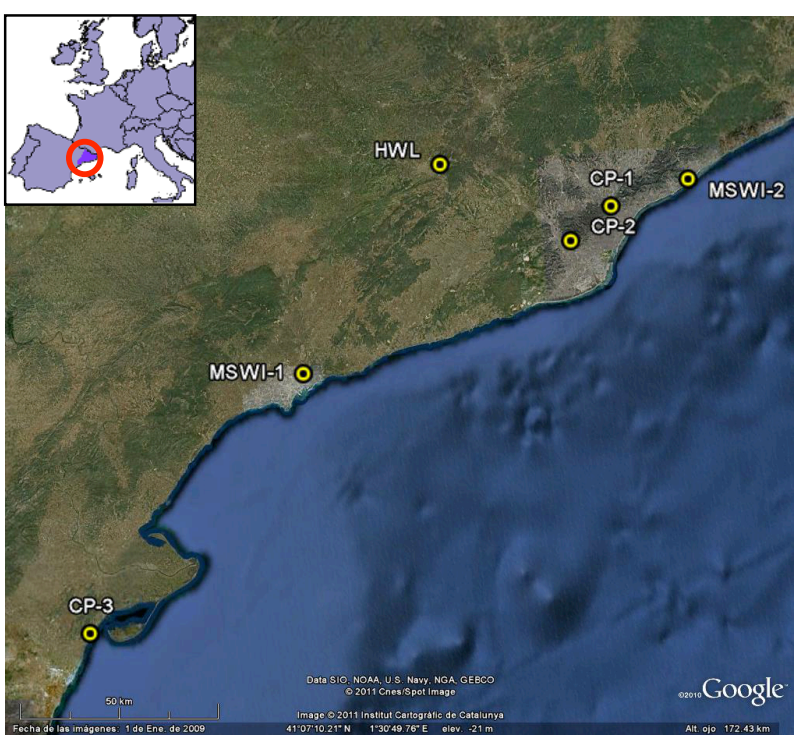

Fig. 1. Sampling points in Catalonia (NE Spain).

significantly release high amounts of particulate matter. ${ }^{7}$ In Barcelona, an increasing trend has been observed for $\mathrm{PM}_{10}$ (particulate matter $<10 \mu \mathrm{m}$ ) levels in the last decade, which should be related to the increase in the traffic flow and the diesel fleet. ${ }^{8}$ Moreover, Catalonia possesses a very intensive industrial activity, which is usually located closed to inhabited nuclei. Cement production seems to be one of the industrial activities which general most concern in terms of emission of dust and particulates. $^{9-11}$ In addition, some waste management plants, such as incinerators and landfills, can also mean an important contribution in the emission of metals, which are sorbed to particulate matter. ${ }^{12}$

The purpose of the present study was to analyze the airborne concentrations of natural uranium in the vicinity of different industrial plants of Catalonia. Furthermore, the health risks associated to the exposure to this element through air inhalation were also assessed for adult people living close to those facilities.

\section{Materials and Methods}

\subsection{Sampling}

Between 2008 and 2010, air samples were collected in the surroundings of 6 industrial facilities in Catalonia: three cement plants (CPs), two municipal solid waste incinerators (MSWIs), and a hazardous waste landfill (HWL). The geographical distribution of these facilities is shown in Fig. 1, while the specific characteristics of each facility are given in Table 1 .

A total number of 84 air samples were collected. Sampling points were selected according to the results of previous modeling studies and the closeness to populated nuclei, with an especial emphasis on sensitive populations (children, old people, etc.). Sampling was performed in the framework of environmental surveillance programs to measure the levels of airborne pollutants around those facilities. The methodology of sampling and analysis have been widely described in recent studies. ${ }^{13,14}$ Immission air samples were collected by using a TE-6070DV high-volume active sampler (Tisch Environmental, Cleves, OH, USA). Particulate matter $\left(\mathrm{PM}_{10}\right)$, where heavy metals are adsorbed, was collected with quartz fiber filter (QFFs).

Sampling volumes were within the range 1934-2840 $\mathrm{m}^{3}$. After their collection, QFFs were properly stored at room temperature in the laboratory until the analysis.

\subsection{Analytical procedures}

The filters were treated with a mixture of $2 \mathrm{~mL}$ of $\mathrm{HNO}_{3}$ (65\% Suprapur; E. Merck, Darmstadt, Germany) and $3 \mathrm{~mL}$ of HF (37.5\%, Panreac SA; Castellar del

Table 1. Main characteristics of the facilities under study.

\begin{tabular}{|c|c|c|c|c|}
\hline Facility & Zone & $\begin{array}{l}\text { Production / } \\
\text { Treatment capacity }\end{array}$ & Input Materials & Fuel \\
\hline $\mathrm{CP}-1$ & Urban & 650,000 tons clinker/year & Clay, limestone & Petroleum coke \\
\hline $\mathrm{CP}-2$ & Suburban & 950,000 tons clinker/year & Clay, limestone & Petroleum coke \\
\hline $\mathrm{CP}-3$ & Rural & $2,300,000$ tons clinker /year & Clay, limestone & Petroleum coke, refused-derived fuel \\
\hline MSWI-1 & Suburban & 140,000 tons/year & Municipal solid waste & Municipal solid waste \\
\hline MSWI-2 & Urban & 164,000 tons/year & Municipal solid waste & Municipal solid waste \\
\hline HWL & Rural & 70,000 tons/year & $\begin{array}{l}\text { Asbestos, incineration } \\
\text { ashes and others }\end{array}$ & - \\
\hline
\end{tabular}

CP: Cement Plant; MSWI: Municipal Solid Waste Incinerator; HWL: Hazardous Waste Landfill. 
Vallès, Barcelona, Spain) in hermetic Teflon bombs for $8 \mathrm{~h}$ at room temperature, and for $8 \mathrm{~h}$ at $80^{\circ} \mathrm{C}$. Subsequently, the extract was evaporated in a sand bath and reconstituted with nitric acid. Uranium (U) concentrations were determined by means of inductively coupled plasma-mass spectrometry (ICP-MS; Elan 6000; Perkin Elmer, Wellesley, MA, USA). Quality control/quality assurance (QC/QA) was checked by the analysis of blanks, internal reference samples and standard materials in each batch.

\subsection{Human health risk assessment}

The human exposure to $U$ was evaluated by applying the USEPA Risk Assessment Guidance for Superfund (RAGS) methodology, ${ }^{15}$ which has been accurately described in recent papers. ${ }^{16,} 17$ The expression to calculate the exposure to $U$ through air inhalation was the following:

$$
\operatorname{Exp}_{\text {inh }}=\frac{\mathrm{C}_{\text {air }} \times \mathrm{IR} \times \mathrm{EF}}{\mathrm{BW} \times 365}
$$

where $\operatorname{Exp}_{\text {inh }}$ is the exposure through air inhalation (in $\mathrm{mg} \mathrm{kg}^{-1}$ day $\left.^{-1}\right), \mathrm{C}_{\text {air }}$ is the air concentration of uranium (in $\left.\mathrm{mg} \mathrm{m}^{-3}\right)$, IR is the inhalation rate $\left(20 \mathrm{~m}^{3}\right.$ day $\left.^{-1}\right)$, EF is the exposure frequency ( 350 days year ${ }^{-1}$ ), and $\mathrm{BW}$ is the body weight for an adult $(70 \mathrm{~kg})$. Afterwards, the noncarcinogenic risks derived from the environmental exposure to $U$ were assessed by calculating the Hazard Quotient (HQ), which is defined as the relation between the exposure concentration (EC) and the reference concentration ( $\mathrm{RfC})$. EC was estimated by applying the following equation:

$$
\mathrm{EC}_{\mathrm{inh}}=\frac{\mathrm{C}_{\mathrm{air}} \times \mathrm{ET} \times \mathrm{EF} \times \mathrm{ED}}{\mathrm{AT} \times 365 \times 24}
$$

where EC is the exposure concentration (in $\mathrm{mg} \mathrm{m}^{-3}$ ), $\mathrm{C}_{\text {air }}$ is the air concentration of uranium (in $\mathrm{mg} \mathrm{m}^{-3}$ ), ET is the exposure time $\left(24 \mathrm{~h} \mathrm{day}^{-1}\right)$, EF is the exposure frequency (350 days year ${ }^{-1}$ ), ED is the exposure duration (30 years), and AT is the averaging time for noncarcinogenic substances (25 years).

\section{Results and discussion}

\subsection{Uranium concentrations in air}

Mean concentrations of $U$ in air samples collected in the vicinity of each industrial facility are summarized in
Table 2. Uranium mean levels ranged between $<0.005$ and $0.248 \mathrm{ng} \mathrm{m}^{-3}$. When considering samples individually, a maximum concentration was found in a sampling point located near CP-1. A high variability of results was observed, as higher concentrations were not correlated to a specific kind of plant. Despite the wide range of values, the mean concentrations of $U$ near cement kilns were reported to be slightly higher than those found in the surroundings of waste management plants, with the exception of MSWI-2.

Table 2. Concentration of uranium (in $\mathrm{ng} \mathrm{m}^{-3}$ ) in air samples collected around various industrial facilities in Catalonia (Spain).

\begin{tabular}{lcccccc}
\hline & Mean & SD & Min & Max & Campaign & $\mathbf{n}$ \\
\hline \multirow{4}{*}{ CP-1 } & 0.052 & 0.017 & 0.030 & 0.077 & Nov. 2009 & 8 \\
& 0.004 & 0.003 & $<0.005$ & 0.009 & May 2009 & 4 \\
& 0.248 & 0.058 & 0.156 & 0.312 & Nov. 2008 & 8 \\
\hline \multirow{3}{*}{ CP-2 } & 0.010 & 0.020 & $<0.005$ & 0.060 & Sept. 2009 & 8 \\
& 0.094 & 0.045 & 0.019 & 0.159 & Sept. 2008 & 8 \\
& 0.095 & 0.048 & 0.014 & 0.169 & March 2009 & 8 \\
\hline \multirow{2}{*}{ CP-3 } & 0.219 & 0.084 & 0.106 & 0.333 & Oct. 2008 & 8 \\
& 0.031 & 0.020 & $<0.005$ & 0.055 & Oct. 2009 & 8 \\
\hline MSWI-1 & 0.011 & 0.013 & $<0.005$ & 0.039 & June 2009 & 8 \\
\hline MSWI-2 & 0.238 & 0.099 & 0.104 & 0.388 & Nov. 2008 & 8 \\
\hline HWL & 0.011 & 0.016 & $<0.005$ & 0.047 & July 2010 & 8 \\
\hline
\end{tabular}

The cement production sector has been identified as an important potential releaser of dust, which is generated through emissions, handling, spillage, leakages, starting with the quarrying of the major raw material limestone and ending with the packing and dispatch of cement from the plant. ${ }^{18}$ Therefore, the geochemical content of the parent material is a key issue to understand the release of elements originally contained in rocks. Dust concentrations of many elements usually reflect those of the local geology. ${ }^{19}$ For instance, it is known that granite rocks have higher amounts of $\mathrm{U}$, among other elements. ${ }^{20}$ Their use as input materials in the cement production chain may mean an emission $U$ increase. Anyhow, the $U$ values of found near cement facilities in several surveys were also very low $\left(0.004-0.031 \mathrm{ng} \mathrm{m}^{-3}\right)$, being similar to those reported in the scientific literature. Gaudry et al. ${ }^{21}$ analyzed the metal concentrations in $\mathrm{PM}_{10}$ particles collected over three sites in France, associated to rural, urban and industrial areas. Mean average levels were 
$0.013,0.0099$ and $0.025 \mathrm{ng} \mathrm{m}^{-3}$, respectively. Moreover, these investigators observed that the mean $U$ level of airborne samples collected in the surroundings of the Saclay village (close to Paris, France) was $0.149 \mathrm{ng} \mathrm{m}^{-3}$, with similar ranges $\left(0.051-0.435 \mathrm{ng} \mathrm{m}^{-3}\right)$ to those found in Catalonia. ${ }^{22}$ On the other hand, $U$ levels were found to be up to $0.2 \mathrm{ng} \mathrm{m}^{-3}$ in sampling sites around Palermo (Italy), ${ }^{23}$ with an average value of $0.02 \mathrm{ng} \mathrm{m}^{-3}$. Similarly to other studies, ${ }^{21}$ winter values were found to be substantially higher than summer levels ( 0.128 vs. 0.030 $\left.n g \mathrm{~m}^{-3}\right)$.

Table 3. Pearson correlation in the levels of other metals vs. uranium in air samples.

\begin{tabular}{cccccc}
\hline $\mathrm{As}$ & 0.123 & $\mathrm{Cu}$ & $-0.435^{*}$ & $\mathrm{Sb}$ & 0.016 \\
$\mathrm{Cd}$ & -0.034 & $\mathrm{Mn}$ & $0.601^{*}$ & $\mathrm{Sn}$ & $0.751^{*}$ \\
$\mathrm{Co}$ & $0.656^{*}$ & $\mathrm{Ni}$ & 0.266 & $\mathrm{Tl}$ & 0.047 \\
$\mathrm{Cr}$ & -0.07 & $\mathrm{~Pb}$ & 0.113 & $\mathrm{~V}$ & 0.047 \\
\hline
\end{tabular}

*Statistically significant $(\mathrm{p}<0.001)$

As above stated, the measurement of $U$ in air samples was performed in the framework of environmental surveillance studies mainly focused on investigating the impact of a number of Catalan industrial facilities. Complementarily to the analysis of $\mathrm{U}$, the concentrations of other trace elements had been previously determined. ${ }^{10,16,17,24-26}$ In order to assess potential associations between metals, a Pearson correlation was executed (Table 3). Uranium was positively correlated with $\mathrm{Sn}$, as well as with $\mathrm{Co}$ and $\mathrm{Mn}$, while a negative association was observed between $\mathrm{Cu}$ and $\mathrm{U}$. Some investigations point out that $\mathrm{Co}, \mathrm{Cu}$ and U are "normal" elements in top beds of phosphate rocks. $^{27}$

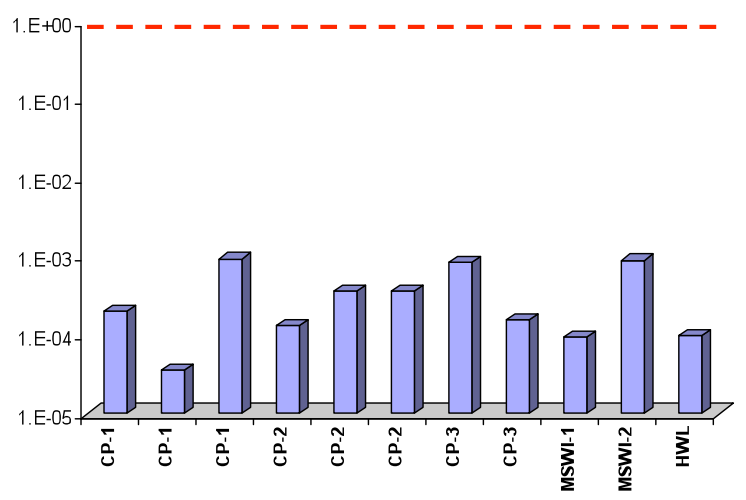

Fig. 2. Hazard Quotient (unitless) of uranium exposure through air inhalation for adults living near various industrial facilities in Catalonia (NE Spain).

\subsection{Human heath risk assessment}

The concentrations of uranium in air samples were used to evaluate human $U$ exposure through air inhalation. The predicted exposure is summarized in Table 4.

Table 4. Predicted exposure to uranium (in $\mathrm{mg}$ $\mathrm{kg}^{-1}$ day $^{-1}$ ) though air inhalation for an adult population living near various industrial facilities in Catalonia (NE Spain).

\begin{tabular}{lcccc}
\hline & Mean & Min & Max & Campaign \\
\hline \multirow{4}{*}{ CP-1 } & $1.43 \mathrm{E}-08$ & $8.33 \mathrm{E}-09$ & $2.10 \mathrm{E}-08$ & Nov. 2009 \\
& $2.60 \mathrm{E}-09$ & $2.60 \mathrm{E}-09$ & $2.60 \mathrm{E}-09$ & May 2009 \\
& $6.80 \mathrm{E}-08$ & $4.28 \mathrm{E}-08$ & $8.54 \mathrm{E}-08$ & Nov. 2008 \\
\hline \multirow{3}{*}{ CP-2 } & $9.42 \mathrm{E}-09$ & $2.35 \mathrm{E}-09$ & $1.65 \mathrm{E}-08$ & Sept. 2009 \\
& $2.58 \mathrm{E}-08$ & $5.34 \mathrm{E}-09$ & $4.35 \mathrm{E}-08$ & Sept. 2008 \\
& $2.60 \mathrm{E}-08$ & $3.82 \mathrm{E}-09$ & $4.64 \mathrm{E}-08$ & March 2009 \\
\hline \multirow{2}{*}{ CP-3 } & $6.01 \mathrm{E}-08$ & $2.90 \mathrm{E}-08$ & $9.14 \mathrm{E}-08$ & Oct. 2008 \\
& $1.11 \mathrm{E}-08$ & $8.00 \mathrm{E}-09$ & $1.49 \mathrm{E}-08$ & Oct. 2009 \\
\hline MSWI-1 & $6.87 \mathrm{E}-09$ & $4.04 \mathrm{E}-09$ & $1.07 \mathrm{E}-08$ & June 2009 \\
\hline MSWI-2 & $6.52 \mathrm{E}-08$ & $2.86 \mathrm{E}-08$ & $1.06 \mathrm{E}-07$ & Nov. 2008 \\
\hline HWL & $7.01 \mathrm{E}-09$ & $2.12 \mathrm{E}-09$ & $1.29 \mathrm{E}-08$ & July 2010 \\
\hline
\end{tabular}

Non-carcinogenic risks were assessed by comparing the exposure concentration to $\mathrm{U}$ with the RfC, set at 300 ng $\mathrm{m}^{-3}$ by the USEPA. ${ }^{28}$ The Hazard Quotient (HW) for each campaign of study is depicted in Fig. 2. It can be observed that the non-cancer risk values were more than two orders of magnitude below the maximum threshold level, established at the unity. It means that the current concentrations of $U$ should not mean any additional non-carcinogenic risk for the population living near the industrial facilities here assessed: three cement plants, two MSWIs, and a hazardous waste landfill. Notwithstanding, it must be noted that $U$ is a toxic element whose environmental levels should be continuously monitored. It is especially important in those sites with the presence of significantly important potential emitters of particulate matter or dust, where metals can be adsorbed.

\section{References}

1. J. L. Domingo, Chemical toxicity of uranium, Toxicol. Ecotoxicol. News 2 (1995) 74-78.

2. V. Linares, M. L. Albina, M. Bellés, E. Mayayo, D. J. Sánchez and J. L. Domingo, Combined action of uranium and 
stress in the rat: II. Effects on male reproduction, Toxicol. Lett. 158 (2005) 186-195.

3. V. Linares, M. Bellés, M. L. Albina, J. J. Sirvent, D. J. Sánchez and J. L. Domingo, Assessment of the pro-oxidant activity of uranium in kidney and testis of rats, Toxicol. Lett. 167 (2006) 152-161.

4. ATSDR, Public Health statement for Uranium, US Public Health Services, Washington, DC (available at http://www.atsdr.cdc.gov/toxprofiles/phs150html), 1999.

5. US EPA, EPA facts about uranium, United States Environmental Protection Agency. Available at http://www.epa.gov/superfund/resources/radiation/pdf/uraniu m.pdf, 2002.

6. J. L. Domingo, Reproductive and developmental toxicity of natural and depleted uranium: A review, Reprod. Toxicol. 15 (2001) 603-609.

7. G. Dongarrà, E. Manno, D. Varrica, M. Lombardo and M. Vultaggio, Study on ambient concentrations of $\mathrm{PM}_{10}$, $\mathrm{PM}_{10-2.5}, \mathrm{PM}_{2.5}$ and gaseous pollutants. Trace elements and chemical speciation of atmospheric particulates, Atmos. Environ. 44 (2010) 5244-5257.

8. N. Pérezi, J. Pey, M. Cusack, C. Reche, X. Querol, A. Alastuey and M. Viana, Variability of particle number, black carbon, and $\mathrm{PM}_{10}, \mathrm{PM}_{2.5}$, and $\mathrm{PM}_{1}$ Levels and Speciation: Influence of road traffic emissions on urban air quality, Aerosol Sci. Technol. 44 (2010) 487-499.

9. G. Kabir and A. I. Madugu, Assessment of environmental impact on air quality by cement industry and mitigating measures: A case study, Environ. Monit. Assess. 160 (2010) 91-99.

10. J. Rovira, M. Mari, M. Schuhmacher, M. Nadal and J. L. Domingo, Monitoring environmental pollutants in the vicinity of a cement plant: A temporal study, Arch. Environ. Contam. Toxicol. 60 (2011) 372-384.

11. S. S. Kumar, N. A. Singh, V. Kumar, B. Sunisha, S. Preeti, S. Deepali and S. R. Nath, Impact of dust emission on plant vegetation in the vicinity of cement plant, Environ. Eng. Manage. J. 7 (2008) 31-35.

12. E. Chalvatzaki, I. Kopanakis, M. Kontaksakis, T. Glytsos, N. Kalogerakis and M. Lazaridis, Measurements of particulate matter concentrations at a landfill site (Crete, Greece), Waste Manage. 30 (2010) 2058-2064.

13. M. Mari, M. Schuhmacher, J. Feliubadaló and J. L. Domingo, Air concentrations of PCDD/Fs, PCBs and PCNs using active and passive air samplers, Chemosphere 70 (2008) 1637-1643.

14. M. Nadal, M. Mari, M. Schuhmacher and J. L. Domingo, Multi-compartmental environmental surveillance of a petrochemical area: Levels of micropollutants, Environ. Int. 35 (2009) 227-235.

15. US EPA, Risk assessment guidance for superfund volume I: human health evaluation manual (part F, supplemental guidance for inhalation risk assessment), United States Environmental Protection Agency. Office of Superfund Remediation and Technology Innovation, EPA-540-R-070002, 2009.

16. J. Rovira, M. Mari, M. Nadal, M. Schuhmacher and J. L. Domingo, Use of sewage sludge as secondary fuel in a cement plant: Human health risks, Environ. Int. 37 (2011) 105-111.

17. J. Rovira, M. Mari, M. Nadal, M. Schuhmacher and J. L. Domingo, Partial replacement of fossil fuel in a cement plant: Risk assessment for the population living in the neighborhood, Sci. Total Environ. 408 (2010) 5372-5380.

18. S. A. Abdul-Wahab, Impact of fugitive dust emissions from cement plants on nearby communities, Ecol. Model. 195 (2006) 338-348.

19. A. Turner and B. Hefzi, Levels and bioaccessibilities of metals in dusts from an arid environment, Water Air Soil Pollut. 210 (2010) 483-491.

20. G. M. A. Bermudez, M. Moreno, R. Invernizzi, R. Plá and M. L. Pignata, Evaluating top soil trace element pollution in the vicinity of a cement plant and a former open-cast uranium mine in central Argentina, J. Soils Sedim. 10 (2010) 1308-1323.

21. A. Gaudry, M. Moskura, C. Mariet, S. Ayrault, F. Denayer and N. Bernard, Inorganic pollution in $\mathrm{PM}_{10}$ particles collected over three French sites under various influences: Rural conditions, traffic and industry, Water Air Soil Pollut. 193 (2008) 91-106.

22. S. Ayrault, A. Senhou, M. Moskura and A. Gaudry, Atmospheric trace element concentrations in total suspended particles near Paris, France, Atmos. Environ. 44 (2010) 37003707.

23. G. Dongarrà, E. Manno, D. Varrica and M. Vultaggio, Mass levels, crustal component and trace elements in $\mathrm{PM}_{10}$ in Palermo, Italy, Atmos. Environ. 41 (2007) 7977-7986.

24. L. Vilavert, M. Nadal, M. Mari, M. Schuhmacher and J. L. Domingo, Modification of an environmental surveillance program to monitor PCDD/Fs and metals around a municipal solid waste incinerator, J. Environ. Sci. Health A 44 (2009) 1343-1352.

25. J. Rovira, M. Mari, M. Nadal, M. Schuhmacher and J. L. Domingo, Environmental monitoring of metals, PCDD/Fs and PCBs as a complementary tool of biological surveillance to assess human health risks, Chemosphere 80 (2010) 11831189.

26. M. Mari, M. Nadal, M. Schuhmacher and J. L. Domingo, Exposure to heavy metals and $\mathrm{PCDD} / \mathrm{Fs}$ by the population living in the vicinity of a hazardous waste landfill in Catalonia, Spain: Health risk assessment, Environ. Int. 35 (2009) 1034-1039.

27. J. Bech, M. Suarez, F. Reverter, P. Tume, P. Sánchez, J. Bech and A. Lansac, Selenium and other trace elements in 
phosphate rock of Bayovar-Sechura (Peru), J. Geochem. Explor. 107 (2010) 136-145.

28. US EPA, Preliminary Remediation Goals, United States

Environmental Protection Agency. Available at: http://www.epa.gov/region09/superfund/prg/. 2010. 